Prepared for the U.S. Department of Energy

under Contract DE-AC05-76RL01830

\title{
Identification and Prioritization of Analysis Cases for Marine and Hydrokinetic Energy Risk Screening
}

Environmental Effects of Marine and Hydrokinetic Energy - Fiscal Year 2010

RM Anderson

SD Unwin

FB Van Cleve

June 2010

\section{Pacific Northwest}

NATIONAL LABORATORY

Proudly Operated by Battelle Since 1965 


\title{
DISCLAIMER
}

This report was prepared as an account of work sponsored by an agency of the United States Government. Neither the United States Government nor any agency thereof, nor Battelle Memorial Institute, nor any of their employees, makes any warranty, express or implied, or assumes any legal liability or responsibility for the accuracy, completeness, or usefulness of any information, apparatus, product, or process disclosed, or represents that its use would not infringe privately owned rights. Reference herein to any specific commercial product, process, or service by trade name, trademark, manufacturer, or otherwise does not necessarily constitute or imply its endorsement, recommendation, or favoring by the United States Government or any agency thereof, or Battelle Memorial Institute. The views and opinions of authors expressed herein do not necessarily state or reflect those of the United States Government or any agency thereof.

\author{
PACIFIC NORTHWEST NATIONAL LABORATORY \\ operated by \\ BATTELLE \\ for the \\ UNITED STATES DEPARTMENT OF ENERGY \\ under Contract DE-AC05-76RL01830 \\ Printed in the United States of America \\ Available to DOE and DOE contractors from the \\ Office of Scientific and Technical Information, \\ P.O. Box 62, Oak Ridge, TN 37831-0062; \\ ph: (865) 576-8401 \\ fax: $(865) 576-5728$ \\ email: reports@adonis.osti.gov

\footnotetext{
Available to the public from the National Technical Information Service,

U.S. Department of Commerce, 5285 Port Royal Rd., Springfield, VA 22161

ph: (800) 553-6847

fax: $(703) 605-6900$

email: orders@ntis.fedworld.gov

online ordering: http://www.ntis.gov/ordering.htm
}

This document was printed on recycled paper 


\title{
Identification and Prioritization of Analysis Cases for Marine and Hydrokinetic Energy Risk Screening
}

\section{Environmental Effects of}

Marine and Hydrokinetic Energy -

Fiscal Year 2010

\author{
RM Anderson \\ SD Unwin \\ FB Van Cleve
}

June 2010

Prepared for

the U.S. Department of Energy

under Contract DE-AC05-76RL01830

Pacific Northwest National Laboratory

Richland, Washington 99352 



\section{Summary}

In this report we present an introduction to the Environmental Risk Evaluation System (ERES), a risk-informed analytical process for estimating the environmental risks associated with the construction and operation of marine and hydrokinetic energy generation projects. The process consists of two main phases of analysis. In the first phase, preliminary risk analyses will take the form of screening studies in which key environmental impacts and the uncertainties that create risk are identified, leading to a betterfocused characterization of the relevant environmental effects. Existence of critical data gaps will suggest areas in which specific modeling and/or data collection activities should take place. In the second phase, more detailed quantitative risk analyses will be conducted, with residual uncertainties providing the basis for recommending risk mitigation and monitoring activities.

We also describe in detail the process used for selecting three cases for fiscal year 2010 risk screening analysis using the ERES. A case is defined as a specific technology deployed in a particular location involving certain environmental receptors specific to that location. The three cases selected satisfy a number of desirable criteria: 1) they correspond to real projects whose deployment is likely to take place in the foreseeable future; 2) the technology developers are willing to share technology and project-related data; 3) the projects represent a diversity of technology-site-receptor characteristics; 4) the projects are of national interest, and 5) environmental effects data may be available for the projects. 


\section{Project Overview}

Energy generated from the world's oceans and rivers offers the potential to make substantial contributions to the domestic and global renewable energy supply. The U.S. Department of Energy (DOE) Office of Energy Efficiency and Renewable Energy (EERE) Wind and Water Power Program supports the emerging marine and hydrokinetic (MHK) energy industry. As an emerging industry, MHK project developers face challenges with siting, permitting, construction, and operation of pilot- and commercial-scale facilities, as well as the need to develop robust technologies, secure financing, and gain public acceptance.

In many cases, little is known about the potential effects of MHK energy generation on the aquatic environment from a small number of devices or a large-scale commercial array. Nor do we understand potential effects that may occur after years or decades of operation. This lack of knowledge affects the solvency of the industry, the actions of regulatory agencies, the opinions and concerns of stakeholder groups, and the commitment of energy project developers and investors.

To unravel and address the complexity of environmental issues associated with MHK, Pacific Northwest National Laboratory (PNNL) is developing a program of research and development that draws on the knowledge of the industry, regulators, and stakeholders and builds on investments made by the EERE Wind and Water Power Program. The PNNL program of research and development - together with complementary efforts of other national laboratories, national marine renewable energy centers, universities, and industry - supports DOE's market acceleration activities through focused research and development on environmental effects and siting issues. Research areas addressed include

- categorizing and evaluating effects of stressors - Information on the environmental risks from MHK devices, including data obtained from in situ testing and laboratory experiments (see other tasks below) will be compiled in a knowledge management system known as Tethys, after the mythical Greek titaness of the sea, to facilitate the creation, annotation, and exchange of information on environmental effects of MHK technologies. Tethys will support the Environmental Risk Evaluation System (ERES) that can be used by developers, regulators, and other stakeholders to assess relative risks associated with MHK technologies, site characteristics, waterbody characteristics, and receptors (i.e., habitat, marine mammals, and fish). Development of Tethys and the ERES will require focused input from various stakeholders to ensure accuracy and alignment with other needs.

- effects on physical systems - Computational numerical modeling will be used to understand the effects of energy removal on water bodies from the short- and long-term operation of MHK devices and arrays. Initially, PNNL's three-dimensional coastal circulation and transport model of Puget Sound will be adapted to test and optimize simulated tidal technologies that resemble those currently in proposal, laboratory trial, or pilot study test stages. This task includes assessing changes to the physical environment (currents, waves, sediments, and water quality) and the potential effects of these changes on the aquatic food webs) resulting from operation of MHK devices at both pilot- and commercial-scale in river and ocean settings.

- effects on aquatic organisms - Testing protocols and laboratory exposure experiments will be developed and implemented to evaluate the potential for adverse effects from operation of MHK devices in the aquatic environment. Initial studies will focus on electromagnetic field effects, noise associated with construction and operation of MHK devices, and assessment of the potential risk of 
physical interaction of aquatic organisms with devices. A variety of fish species and invertebrates will be used as test animals, chosen due to their proximity to and potential susceptibility to MHK devices.

- permitting and planning - Structured stakeholder communication and outreach activities will provide critical information to the project team to support execution of other project tasks. Input from MHK technology and project developers, regulators and natural resource management agencies, environmental groups, and other stakeholder groups will be used to develop the user interface of Tethys, populate the database, define the risk attributes of the ERES, and communicate results of numerical modeling and laboratory studies of exposure of test animals to MHK stressors. This task will also include activities to promote consideration of renewable ocean energy in national and local Coastal and Marine Spatial Planning activities.

The team for the Environmental Effects of MHK Development project is made up of staff, faculty, and students from

- Pacific Northwest National Laboratory

○ Marine Sciences Laboratory (Sequim and Seattle, Washington)

○ Risk and Decision Sciences (Richland, Washington)

○ Knowledge Systems (Richland, Washington)

- Oak Ridge National Laboratory (Oak Ridge, Tennessee)

- Sandia National Laboratories (Albuquerque, New Mexico; Carlsbad, California)

- Oregon State University, Northwest National Marine Renewable Energy Center (Newport, Oregon)

- University of Washington, Northwest National Marine Renewable Energy Center (Seattle, Washington)

- Pacific Energy Ventures (Portland, Oregon). 


\section{Acronyms and Abbreviations}

DOE

EERE

EMF

ERES

FERC

FY

MHK

PNNL
U.S. Department of Energy

DOE Office of Energy Efficiency and Renewable Energy

electromagnetic field

Environmental Risk Evaluation System

Federal Energy Regulatory Commission

fiscal year

marine and hydrokinetic

Pacific Northwest National Laboratory 


\section{Contents}

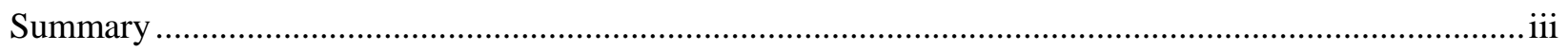

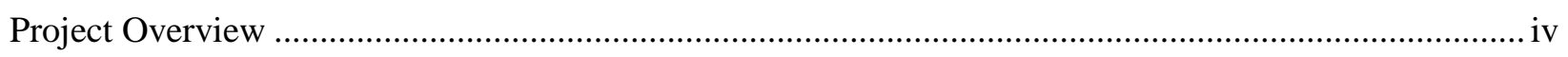

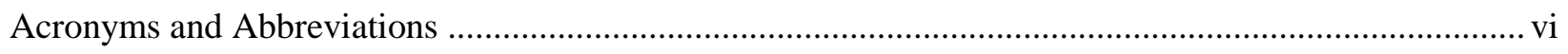

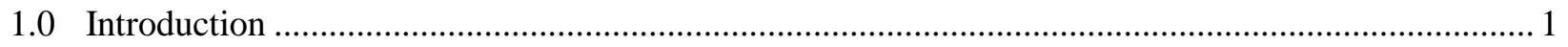

2.0 Development of Marine and Hydrokinetic Risk-Informed Decision Framework ............................ 2

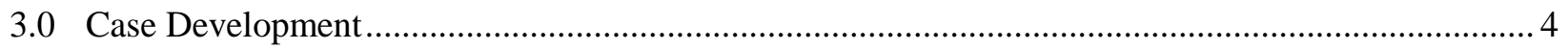

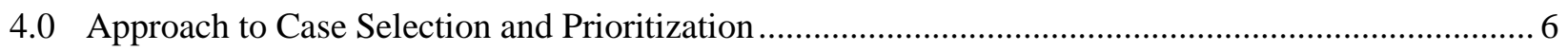

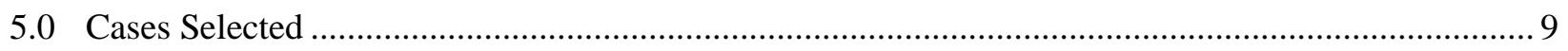

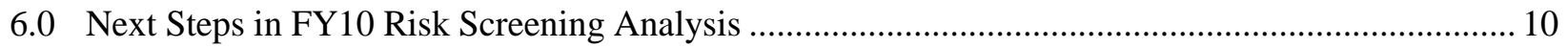

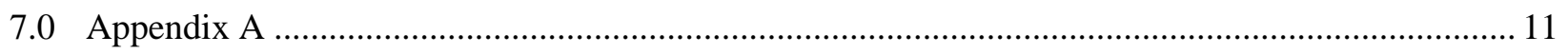

\section{Figures}

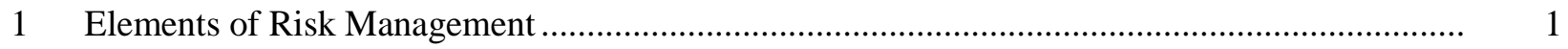

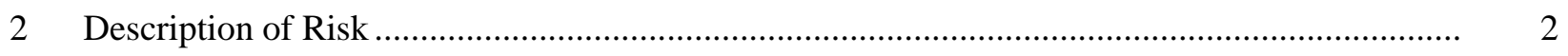

3 Risk-Informed Analytical Process …................................................................................... 3

4 Dimensions, Attributes, States, and Cases ........................................................................ 5

$5 \quad$ Representation of Space Coverage …............................................................................. 7

6 Case Selection Criteria and Decision Pathway ................................................................ 8

\section{Table}

1 Case Satisfaction Criteria for FY10 Screening Analysis .................................................. 10 



\subsection{Introduction}

The concept of risk is basic to human experience in that we all evaluate decisions and situations in terms of their potential to lead to outcomes that are either favorable or unfavorable. A great variety of issues (e.g., societal, economic, and political priorities) influence attitudes and decision making associated with the development and commercialization of marine and hydrokinetic (MHK) technologies. In addition to these issues, stakeholders and decision makers also need to be risk-informed. That is, they need to have access to information and processes that allow identified risk and resulting uncertainties to be systematically and consistently taken into account in decision making related to investment, regulation, design, and operation of MHK technologies. The risk-informed approach described in this report will help the stakeholder and decision makers to assess their tolerance toward risk, determine how to prioritize research activities and issues, and compare the costs and benefits of different options. Figure 1 depicts a general framework for management of risks as it is often applied in engineered and natural systems management contexts. In particular, the boxes on the right-hand side illustrate the view that managing environmental risk - the focus of this study - will facilitate management of regulatory and, ultimately, investment risk.

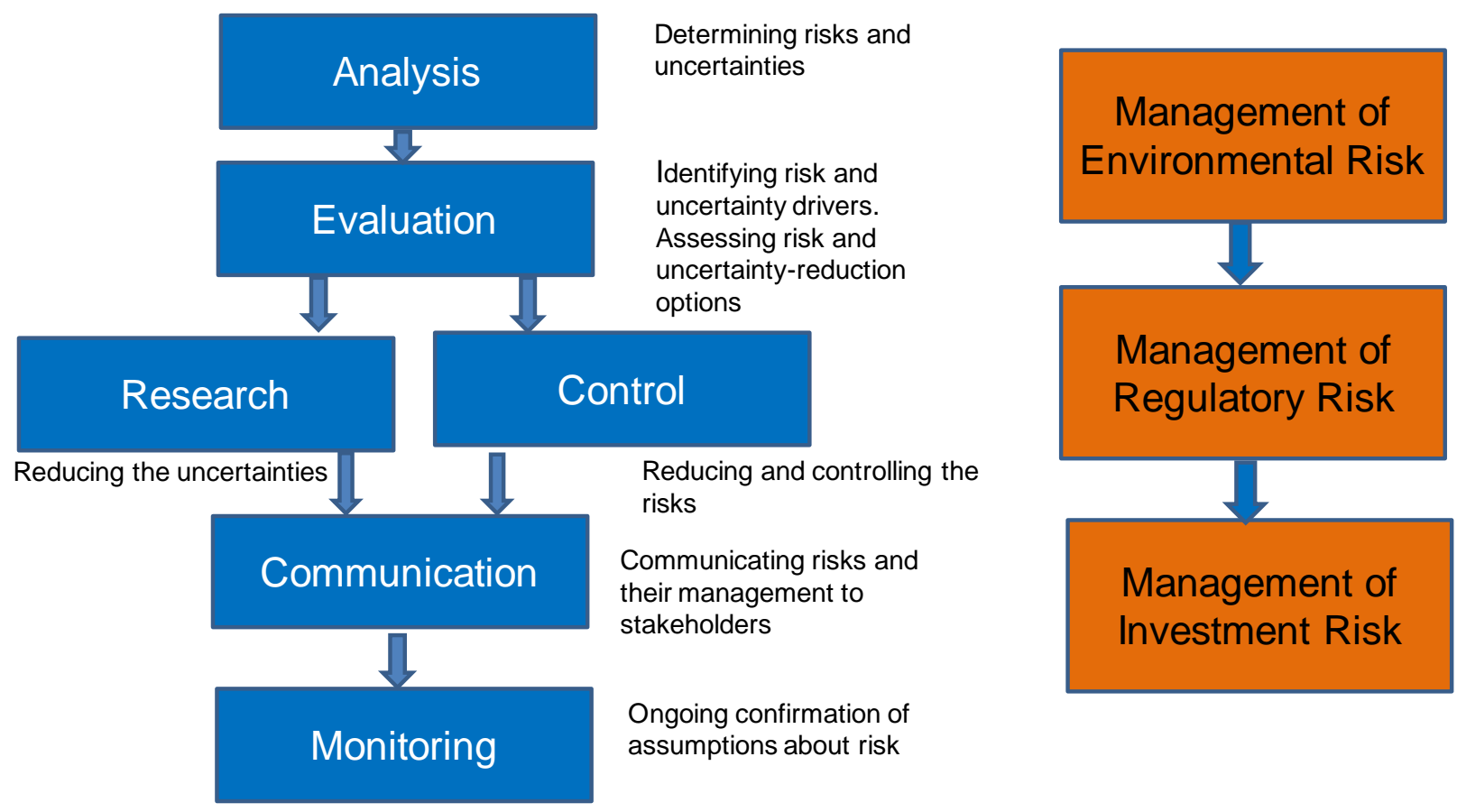

Figure 1. Elements of Risk Management

The risk assessment process begins with the identification and description of scenarios, resulting from sequences of events that lead to adverse impacts (Figure 2). It is useful to distinguish between scenarios that are episodic and, at the other end of the spectrum, those that are chronic. Episodic scenarios involve events that may or may not take place and are thus characterized by their likelihood or rate of occurrence. They are also characterized by the degree of impact or severity of their consequences. An example of an episodic scenario would be collision of a vessel with an MHK device or array of devices. The likelihood 
of occurrence would be related to factors such as vessel traffic volume and the proximity of shipping lanes to the devices. Consequences could include environmental damage due to spills and financial loss due to damaged property or loss of generation of power. In contrast, chronic risk scenarios involve events or circumstances that are always in effect so that risk characterization involves assessing only the severity of the consequences. An example of a chronic risk scenario would be low-level chemical releases from anti-biofouling coatings used on device structures. Between these two extremes, we may also identify an intermediate category of intermittent events. These are really episodic but are of high enough frequency that they are anticipated. Here, an example would be adverse impacts to animals associated with turbine rotation such as blade strike. A key feature of understanding risk is describing the uncertainty associate with the occurrence of an episodic, intermittent, or chronic event, as well as the uncertainty of the resulting consequences. This analysis will limit its focus to environmental effects.

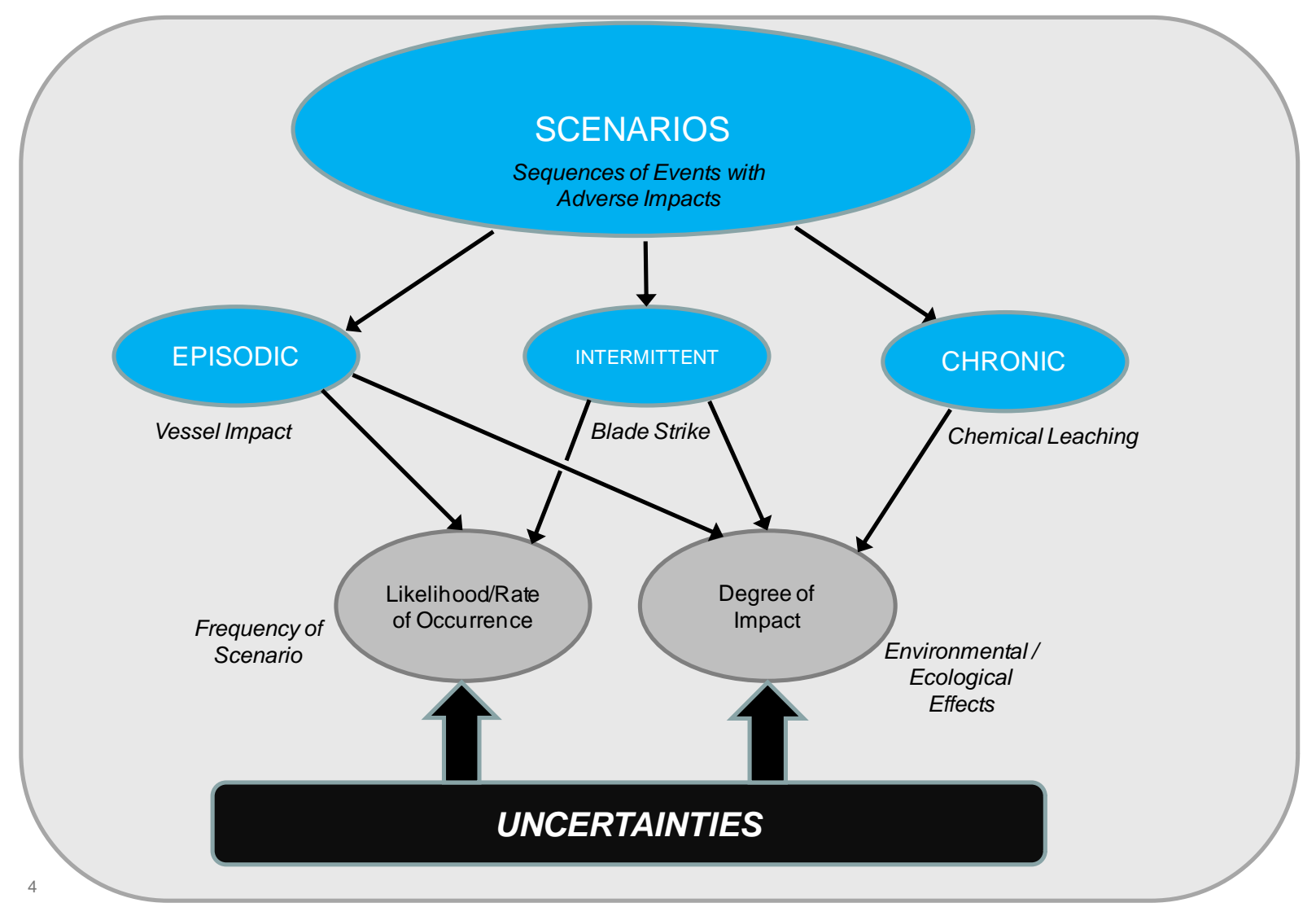

Figure 2. Description of Risk

\subsection{Development of Marine and Hydrokinetic Risk-Informed Decision Framework}

As part of the EERE MHK program, we will develop and implement a multi-phase risk methodology that can be applied to, and used to select among, a wide range of technologies and siting options, and to prioritize research directed towards uncertainty reduction. The overall process is depicted in Figure 3. 
One challenge for a risk-informed approach to the analysis and management of MHK technologies is the diversity of existing and prospective device designs and environments in which they might operate. This report will describe a process of identifying and prioritizing specific case studies (devices deployed in specific locations) for analysis. The process will be guided by stakeholder review and is represented in the first three boxes (blue) in Figure 3.

As shown in the next five boxes (green) in Figure 3, preliminary-phase (phase 1) risk analyses will take the form of screening studies in which key environmental impacts and risks are identified and key uncertainties are characterized relative to the cases selected. Key uncertainties are those to which our assessments of scenario likelihoods or impacts, and thus of risk, are highly sensitive. There will be multiple rounds of screening studies as new cases are selected for analysis. This initial phase of analysis will lead to more finely resolved definitions of ecological impact scenarios (stressors, receptors, impact mechanisms) and suggest specific data collection efforts or model improvements in an attempt to resolve identified risk-critical uncertainties.

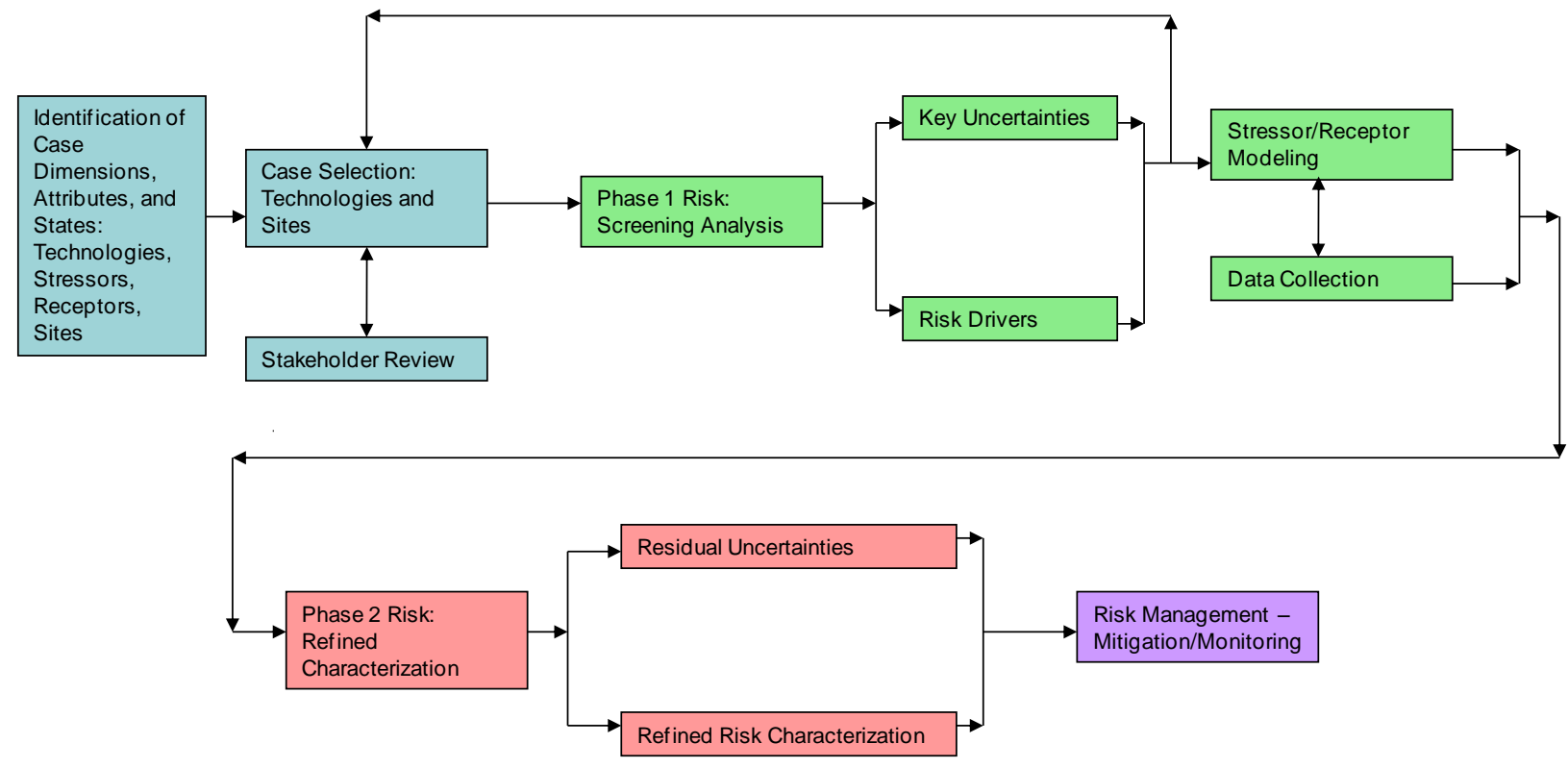

Figure 3. Risk-Informed Analytical Process

The next three boxes (red) refer to a more detailed and more quantitative phase (phase 2) of risk analysis that will be based on improved scenario characterization and augmented data generated in the previous steps. The more refined characterization of risk and residual uncertainties that remain after this stage forms the basis for choosing appropriate actions for managing risk, as indicated in the final box (purple). Unacceptable risks and large uncertainties may be addressed through additional modeling and data collection efforts, while sensitivity and importance analyses will be used to identify effective risk mitigation strategies and monitoring approaches. 


\subsection{Case Development}

Given the impracticality of capturing all technologies and siting features in a single round of analysis, the concept of an analysis case is introduced. Case studies will allow the sequencing of analyses within each phase of this environmental effects project. A case is defined as a combination of an MHK technology (such as a specific tidal, wave, or instream device) and a deployment site, where the latter is defined by waterbody and site features and the specific set of environmental receptors potentially at risk. The cases selected will provide the vehicle for the development of risk and decision methodology, and for this reason it is important that they capture a broad range of device, siting, stressor, receptor, and uncertainty issues. In this way, the cases initially considered will help set methodological precedents for application to a wide range of subsequent risk analyses for other devices and site/receptor characteristics. It is crucial that the cases initially selected for analysis represent a broad range of risk issues.

Identifying cases relies to some extent on our current understanding of which technology and siting features are likely to drive the risk. For example, the design and technology features selected to distinguish between cases are chosen to reflect the distinguishing risk characteristics anticipated. In this way, a case is intended to represent a class of devices that possess risk-relevant features (to be defined below as attributes). We expect that our understanding of which features are and are not risk relevant will evolve as the analysis proceeds.

A systematic approach to the selection and prioritization of cases is being developed, in which the goal is to produce an objective, transparent, and easily reviewable process. This report outlines the current version of that approach and identifies the analysis cases that have been selected as a result of its application. We begin by describing how an analysis case is defined. Next, the basis for case selection is outlined. Finally, the case selections are identified.

The key dimensions of an analysis case define the power-generating technology, the siting of its deployment at the site and waterbody scale, and the potential environmental receptors. Each dimension can be defined more specifically by the state of different attributes associated with that dimension: for example, for an axial flow turbine, axial flow would be a state, orientation with respect to flow would be an attribute, and MHK Technology would be the dimension. That is, a case is defined as a specific combination of states associated with each attribute across the four dimensions. Figure 4 summarizes the relationships between cases, dimensions, attributes, and states.

In the following sections, we will discuss the key dimensions, the types of attributes, and the states associated with each attribute. Following that, we outline our approach to case identification and prioritization. These discussions are intended to convey a sense of the bases for identifying attributes and corresponding states. The taxonomy of dimensional attributes and states resulting from this approach is shown in Appendix A.

Four key dimensions are identified: MHK technology, waterbody features, site characteristics, and receptors. As already described, the intent in defining the attributes and states of each dimension is to identify features that are likely to display contrasting risk characteristics. 


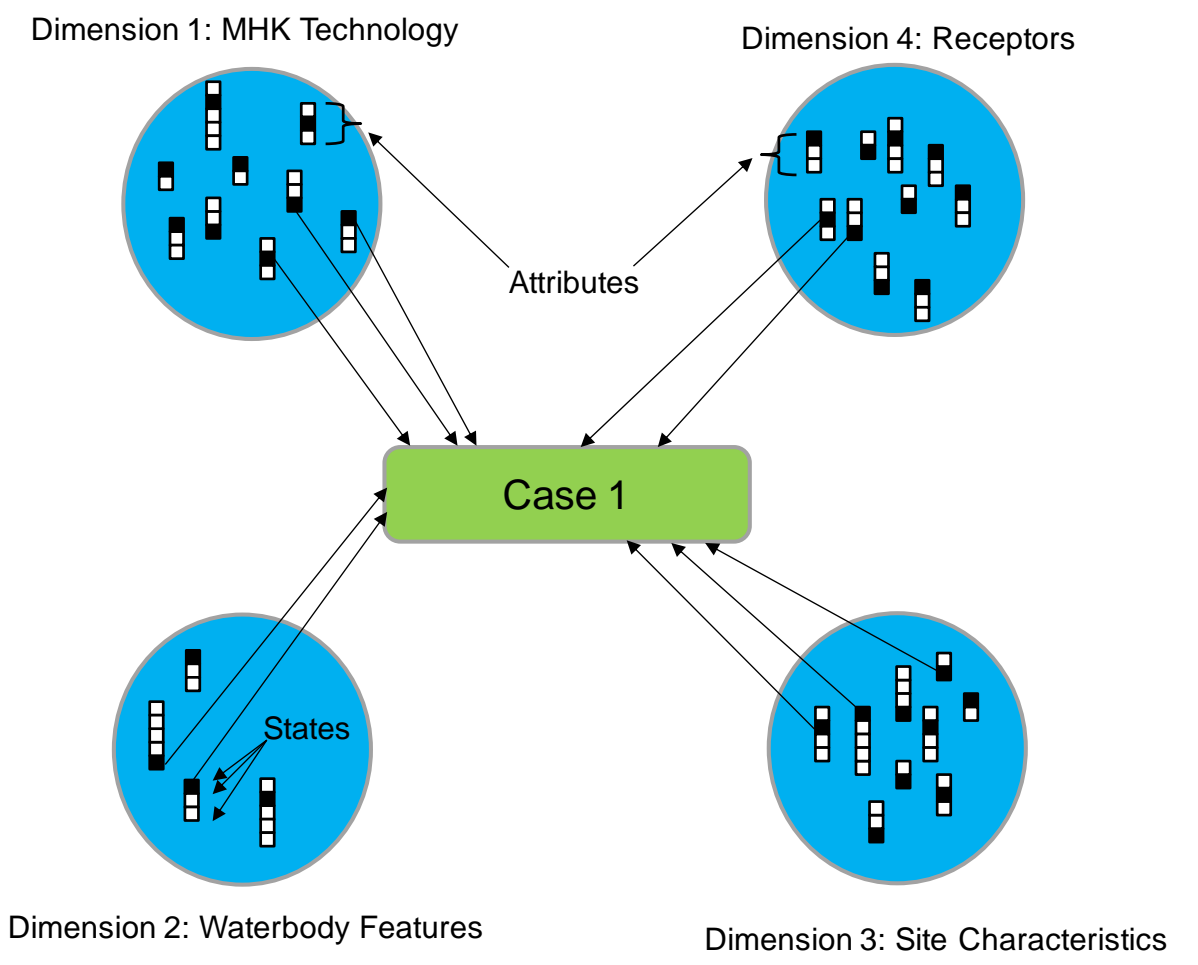

Figure 4. Dimensions, Attributes, States, and Cases

Dimension 1: MHK Technology -The types of stressors distinguish the risk impacts of various MHK power generation technologies as does the degree of impact each might cause. The major MHK technologies we will address are tidal, wave, and riverine. Although there may be some commonality of relevant environmental stressors between these categories, they also have distinguishing stressor attributes. Less clear is the extent to which attributes within each of these categories affect stressors and so we have adopted a conservative approach to distinguishing attributes. For example, with respect to blade strike, one potentially relevant attribute is whether the rotor blades are ducted. Therefore, a case associated with unducted blades will provide some insight into the class of all horizontal turbine systems but will not address effects associated specifically with ducting. If the importance of this effect is significant, or both significant and uncertain, turbine ducting is a legitimate, risk-relevant attribute. Additional risk-relevant attributes within this category for blade strike may be device size, rotational speeds, and power rating; these attributes might also be risk-relevant attributes for noise and electromagnetic field (EMF) stressors.

Dimension 2: Waterbody Features - Waterbody features are differentiated by attributes that reflect the variety of waterbody types, including estuarine, coastal, open ocean, or riverine, in either tropical, temperate, or subarctic climatic zones. This dimension also includes water quality attributes (e.g., salinity, temperature, turbidity) and physical attributes at the waterbody scale (e.g., prevailing wind, frequency of storm events, tidal regime).

Dimension 3: Site Characteristics - This dimension is made up of site-specific physical features, including current speed and flow, wave height, and water depth. Because most MHK devices are gravity mounted or moored to the seabed, an important set of attributes describes the nature of the benthic environment and habitats present at the site. Physical attributes include typical sediment grain sizes and 
whether the substrates are hard and stable or soft and easily mobilized. Biological attributes categorize benthic vegetation type.

Dimension 4: Receptors - This dimension includes biological attributes of ecological, cultural, or economic importance that may be present at the MHK project site and have the potential to be directly or indirectly impacted by MHK development or operation. Attributes characterize seasonality of presence of important species groups (e.g., whales, reef fishes, diving birds), behavior at the project site, and special status or regulatory protections in place. The receptor dimension also includes attributes to characterize presence and special status of high-value habitats, including coral and rocky reefs, kelp forests, seagrass beds, and deep water corals or sponges. Water quality and sediment transport patterns are also included as receptors that may be affected by MHK energy development.

\subsection{Approach to Case Selection and Prioritization}

As previously outlined, the greater the degree to which the set of cases chosen for analysis spans the analytical space of attributes and states, the greater the likely value of those analyses as methodological precedents (Figure 5). Therefore, one objective of the selection methodology is to choose cases for nearterm analysis that, in combination, capture the greatest diversity of attributes and states.

At the same time, we wish to avoid an abstract approach is which we address purely hypothetical state combinations. Rather, we wish to connect the studied cases to existing or pending technologies and projects. The EERE MHK Technology Database ${ }^{1}$ and the Federal Energy Regulatory Commission (FERC) MHK project permit database ${ }^{2}$ were used to determine whether cases represented mature projects likely to be developed.

Developer willingness to participate in this process is an important criterion for selection of cases. Cases will not be selected if the attention on that case will have real or perceived negative impact on the project. Willingness to participate is crucial because risk evaluation will require access to project plans, studies, and data.

The approach to case selection entailed a three-step, iterative process:

1. Compilation of Attributes and States - In this first step, the initial lists of attributes and states associated with each of the dimensions were compiled. These are shown in Appendix A.

2. Stakeholder Feedback - In this second step we met with three important stakeholder groups to discuss the dimensions/attributes/case approach to case selection and elicit feedback. On April 13, 2010, representatives of the ocean energy industry met in Seattle, Washington. On April 13 and May 27, 2010 federal and state regulatory agency representatives met in Seattle, and on June 17, 2010 we met with representatives from environmental organizations through a webex-supported teleconference. Participants were presented with the case selection process, including three preliminary cases, and invited to provide feedback. The discussions that took place contributed to the development of the set of criteria currently being implemented in choosing cases (Figure 6). Three cases were identified based on these discussions.

\footnotetext{
${ }^{1}$ Accessible at http://www1.eere.energy.gov/windandhydro/hydrokinetic/about.aspx (June 2010).

${ }^{2}$ Accessible at http://www.ferc.gov/industries/hydropower/indus-act/hydrokinetics.asp (June 2010).
} 
3. Coverage of Analytical Space - For FY 10, the attributes and states of the three cased identified through discussion stakeholders were compared to the table of attributes and states (Appendix A) to ensure broad coverage of the analytical space. For the MHK Technology Dimension, the states that will be used in FY 10 analysis are highlighted in Figure 5. Figure 5 (and the equivalent for other dimensions) thus provides a confirming visualization that the analytical space is being captured. The cases identified at this step represent hypothetical but credible attribute-state combinations (for example, large marine mammals as receptors would not be an element selected in combination with riverine devices).

\begin{tabular}{|c|c|c|c|c|c|c|}
\hline DIMENSION & ATTRIBUTE & STATE 1 & STATE 2 & STATE 3 & STATE 4 & STATE 5 \\
\hline \multicolumn{7}{|c|}{\begin{tabular}{|l|} 
Operational (includes installation, operation, maintenance, decommissioning) \\
\end{tabular}} \\
\hline MHK Technology & Max rotational speed of device (RPM) & $10-15$ & $15-20$ & $20-30$ & $>30$ & None \\
\hline MHK Technology & Tip speed of device $(\mathrm{m} / \mathrm{s})$ & $0-5$ & $5-10$ & $>10$ & None & \\
\hline MHK Technology & Direction of generation & One way & Two-way & N/A & & \\
\hline MHK Technology & Adjustable turbine speed & Yes & No & N/A & & \\
\hline MHK Technology & Time to shut down & $0-6 \mathrm{sec}$ & 6-15sec & $>15 \mathrm{sec}$ & N/A & \\
\hline MHK Technology & Removable rotor for maintenance & Yes & No & & & \\
\hline MHK Technology & Average hours of power generation per day & $<12$ & $12--18$ & $>18$ & & \\
\hline MHK Technology & Emergency removal time (hrs) & $<12$ & $12--24$ & $>24$ & & \\
\hline \multirow[t]{2}{*}{ MHK Technology } & Time to decommission & $12--24$ hours & 1 day - 1 week & $>1$ week & & \\
\hline & Geometry and orientation & & & & & \\
\hline MHK Technology & Project status & pilot & commercial & & & \\
\hline MHK Technology & Number of devices & $0-3$ & $3--10$ & $10--50$ & $>50$ & \\
\hline MHK Technology & Geometry & cross channel/paralle & along channel/perpe & other configuration & & \\
\hline MHK Technology & Vertical location in water column & Surface & Bottom & Water column & Mid & \\
\hline \multirow{2}{*}{ MHK Technology } & Orientation wrt wave direction & Parallel/overtopping & Perpendicular & Point & Overtopping & N/A \\
\hline & $\begin{array}{r}\text { Rotor Configuration } \\
\end{array}$ & & & & & \\
\hline MHK Technology & Size of turbine swept area $\left(\mathrm{m}^{2}\right)$ & $20-60$ & $60-100$ & $100-200$ & $200-500$ & None \\
\hline MHK Technology & Orientation of axis wrt flow & Axial & Transverse & N/A & & \\
\hline MHK Technology & Orientation of blades wrt axis & Perpendicular & Parallel & N/A & & \\
\hline MHK Technology & Shape of leading edge of turbine blade & Rounded & Sharp & N/A & & \\
\hline MHK Technology & Pitched blades & Yes, fixed & Yes, adjustable & No & N/A & \\
\hline MHK Technology & Rotor diameter $(\mathrm{m})$ & $5-7$ & $7-10$ & $10-15$ & None & \\
\hline MHK Technology & Dynamic rotor seal & Yes & No & N/A & & \\
\hline \multirow[t]{2}{*}{ MHK Technology } & Gearbox & Yes & No & & & \\
\hline & Device Configuration & & & & & \\
\hline MHK Technology & Yaw mechanism & Yes & No & & & \\
\hline MHK Technology & Ducted/venturi & No duct & Shallow duct & Shallow venturi & Deep venturi & \\
\hline MHK Technology & External generator & Yes & No & & & \\
\hline MHK Technology & Turbine/generator located onsite in water & Yes & No & & & \\
\hline MHK Technology & Surface-Piercing & Yes & No & & & \\
\hline MHK Technology & Power rating of device $(\mathrm{kW})$ & $10-50$ & $50-100$ & $100-1000$ & $>1000$ & \\
\hline MHK Technology & Approximate power output at $2.5 \mathrm{~m} / \mathrm{s}(\mathrm{kW})$ & $10-50$ & $50-100$ & $100-200$ & $>200$ & \\
\hline MHK Technology & Power cable location & Buried & Surface-laid & & & \\
\hline MHK Technology & Cable landfall & Directional drilling & Through nearshore & & & \\
\hline MHK Technology & Coupled with bidirectional airflow turbine & Yes & No & & & \\
\hline MHK Technology & Impedance matching of waves & Yes & No & & & \\
\hline \multirow[t]{2}{*}{ MHK Technology } & Adjustable natural resonance frequency & Yes & No & None & & \\
\hline & \begin{tabular}{|l|} 
Fouling, Corrosion Protection \\
\end{tabular} & & & & & \\
\hline MHK Technology & Anti-fouling coating/paint & Yes & No & & & \\
\hline MHK Technology & Surface area covered by anti-fouling coating/paint (m & $0-30$ & $30-60$ & $>60$ & None & \\
\hline \multirow[t]{2}{*}{ MHK Technology } & Composition of anti-fouling coating/paint & Toxic & Non-toxic & None & & \\
\hline & \begin{tabular}{|c|} 
Lubrication \\
\end{tabular} & & & & & \\
\hline \multirow[t]{2}{*}{ MHK Technology } & Bearings & Yes & No & & & \\
\hline & \begin{tabular}{|r|} 
Mooring/Foundation \\
\end{tabular} & & & & & \\
\hline MHK Technology & Footprint on bottom ()m $\mathrm{m}^{2}$ & $5-8$ & $8-11$ & $11-14$ & $>14$ & \\
\hline MHK Technology & Distance from edge of waterway & $0-20 m$ & $20-60 m$ & $60-150 m$ & $>150 m$ & \\
\hline MHK Technology & Mooring method & Gravity-mounted & Driven piles & Anchored & & \\
\hline MHK Technology & Cables & Slack & Taut & N/A & & \\
\hline
\end{tabular}

Figure 5. Representation of Space Coverage 


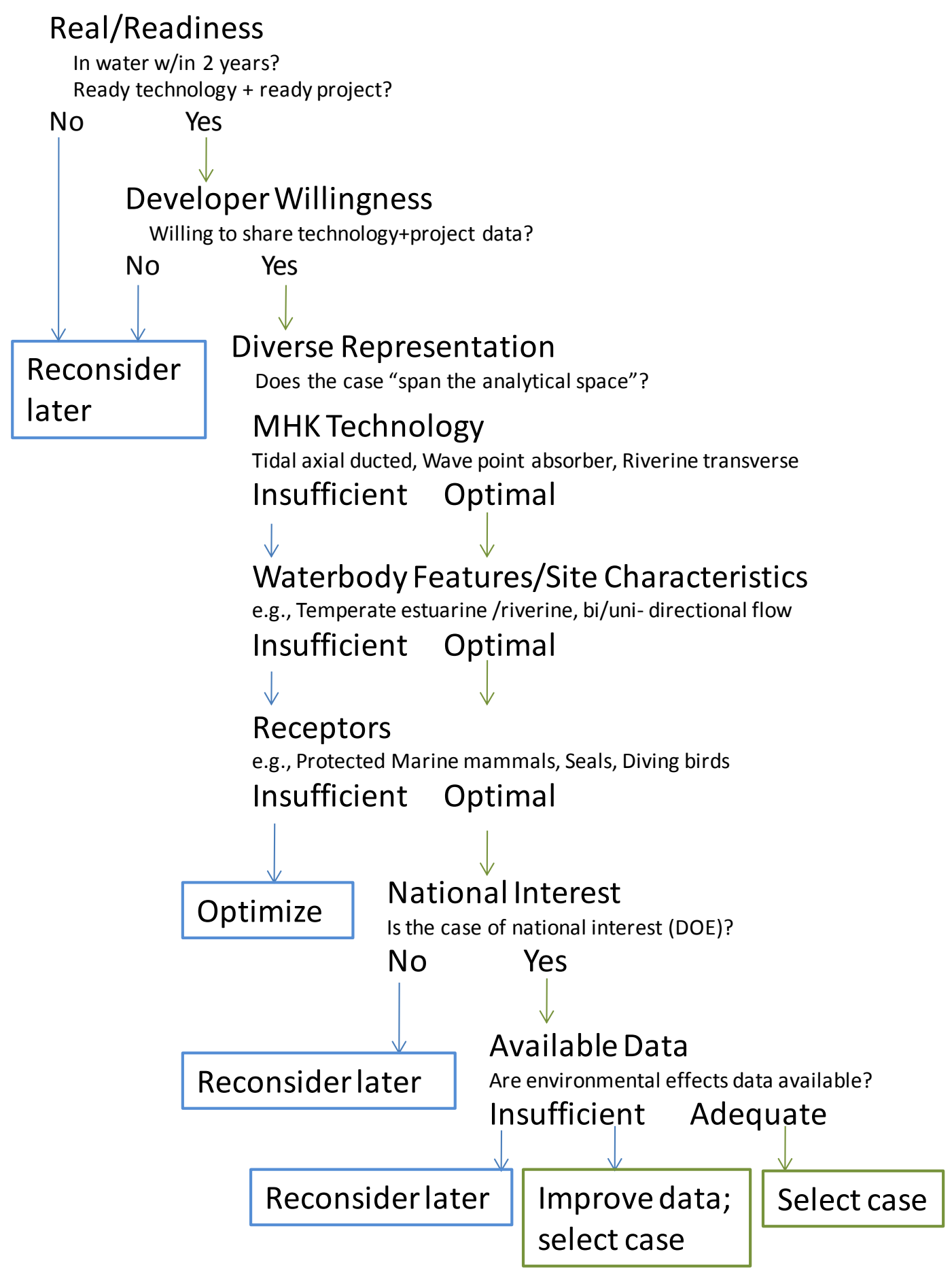

Figure 6. Case Selection Criteria and Decision Pathway 


\subsection{Cases Selected}

The previous section describes the approach to analysis case selection. To reiterate, cases are chosen based on their collective ability to span the analytical space, project maturity and realness, and the willingness of the developer to participate in the risk analysis. An additional criterion is used to affirm case selection: the candidate case must be of national interest. In addition, the availability of environmental effects data is desirable.

The three cases are as follows, described in terms of key entries from each of the four dimensions:

- Open-Center Turbine (Open Hydro, www.openhydro.com) in Admiralty Inlet, Puget Sound, Washington - a ducted, axial flow technology in a temperate, estuarine waterbody; a site with bidirectional water flow, where protected whales, salmon, reef fish, and diving birds are key receptors of concern

- Free-Flow Power Turbine (Free Flow Power Corporation, www.free-flow-power.com) in Baton Rouge, Louisiana (Scotlandville Bend, Mississippi River) - a ducted, axial flow technology in a riverine system; unidirectional water flow, with migratory birds, waterfowl, and protected sturgeon as key receptors

- PowerBuoy Wave Device (Ocean Power Technologies, www.oceanpowertechnologies.com) off Reedsport, Oregon - a point absorber wave energy converter deployed on a surface buoy in a deepwater temperate ocean site; pinnipeds, seabirds, and protected, migratory whales are key receptors of concern.

Table 1 demonstrates how each of the chosen cases meets the criteria for selection. 
Table 1. Case Satisfaction Criteria for FY10 Screening Analysis

\begin{tabular}{|c|c|c|c|c|}
\hline \multicolumn{5}{|c|}{ MHK Cases } \\
\hline & $\begin{array}{l}\text { Open-Center } \\
\text { Turbine }\end{array}$ & $\begin{array}{l}\text { Free Flow Power } \\
\text { Turbine }\end{array}$ & $\begin{array}{l}\text { Power Buoy Wave } \\
\text { Device }\end{array}$ & Collectively \\
\hline \multicolumn{5}{|l|}{ Selection criteria } \\
\hline $\begin{array}{l}\text { Project readiness } \\
\text { and realness }\end{array}$ & $\begin{array}{l}\text { Preliminary permit } \\
\text { issued by FERC }\end{array}$ & $\begin{array}{l}\text { Preliminary permit } \\
\text { issued by FERC }\end{array}$ & $\begin{array}{l}\text { Preliminary permit } \\
\text { issued by FERC }\end{array}$ & \\
\hline $\begin{array}{l}\text { Developer } \\
\text { willingness to } \\
\text { participate in the } \\
\text { risk analysis }\end{array}$ & Yes & Yes & Yes & \\
\hline $\begin{array}{l}\text { Collective ability } \\
\text { to span the } \\
\text { analytical space }\end{array}$ & - & - & - & $\begin{array}{l}\text { Adequate. The } \\
\text { three cases are } \\
\text { described by a } \\
\text { diversity of } \\
\text { attributes and } \\
\text { states }\end{array}$ \\
\hline National interest & $\begin{array}{l}\text { First utility- } \\
\text { sponsored tidal } \\
\text { energy project; } \\
\text { DOE investment }\end{array}$ & $\begin{array}{l}\text { First commercial- } \\
\text { scale in-river } \\
\text { project in the } \\
\text { United States. }\end{array}$ & $\begin{array}{l}\text { First commercial- } \\
\text { scale project in the } \\
\text { United States; } \\
\text { DOE investment }\end{array}$ & \\
\hline $\begin{array}{l}\text { Availability of } \\
\text { environmental } \\
\text { data }\end{array}$ & $\begin{array}{l}\text { Adequate baseline } \\
\text { available }\end{array}$ & $\begin{array}{l}\text { Adequate baseline } \\
\text { available }\end{array}$ & $\begin{array}{l}\text { Adequate baseline } \\
\text { and some early } \\
\text { effects data }\end{array}$ & \\
\hline
\end{tabular}

\subsection{Next Steps in FY10 Risk Screening Analysis}

Stakeholder review of ERES will continue throughout the summer of 2010, concurrently with the risk screening analysis. An important first step for screening analyses will be to identify a list of scenarios that are of greatest concern and the factors that influence the outcomes: likelihoods, impacts, and uncertainties. The attributes listed in Appendix A become the catalog of factors that potentially influence scenario outcomes. For example, the generation of EMF due to normal device operation is a potentially hazardous scenario, and influencing factors include those associated with the particular technology (e.g., its operational details, geometry and orientation, and device configuration; see Appendix A). Conceptual models will be identified that relate stressors to receptors for the selected scenarios as a function of the influencing factors. At the screening stage, these conceptual models will likely be based largely on expert judgment. Uncertainties associated with both lack of knowledge about processes and parameters as well as uncertainty due to natural variability of processes and parameters will influence outcome uncertainty and thus risk to receptors. From these analyses, key impacts, uncertainties, and risk drivers will be identified and ecological impact scenarios refined to focus on these risk-critical uncertainties for the next, more quantitative stage of risk analysis. 


\subsection{Appendix A}

\section{Dimensions, Attributes, and States}

\begin{tabular}{|c|c|c|c|c|c|c|c|}
\hline DIMENSION & ATTRIBUTE & STATE 1 & STATE 2 & STATE 3 & STATE 4 & STATE 5 & STATE 6 \\
\hline & Operational & & & & & & \\
\hline MHK Technology & Max rotational speed of device (RPM) & $10-15$ & $15-20$ & $20-30$ & $>30$ & N/A & \\
\hline MHK Technology & Tip speed of device $(\mathrm{m} / \mathrm{s})$ & $0-5$ & $5-10$ & $>10$ & N/A & & \\
\hline MHK Technology & Direction of generation & One way & Two-way & N/A & & & \\
\hline MHK Technology & Adjustable turbine speed & Yes & No & N/A & & & \\
\hline MHK Technology & Time to shut down & $0-6 \sec$ & $6-15 \mathrm{sec}$ & $>15 \mathrm{sec}$ & & & \\
\hline MHK Technology & Removable rotor for maintenance & Yes & No & $\mathrm{N} / \mathrm{A}$ & & & \\
\hline MHK Technology & Average hours of power generation per day & $<12$ & $12--18$ & $>18$ & & & \\
\hline MHK Technology & Emergency removal time (hrs) & $<12$ & $12--24$ & $>24$ & & & \\
\hline MHK Technology & Time to decommission & $12--24$ hours & 1 day - 1 week & $>1$ week & & & \\
\hline \multirow[t]{2}{*}{ MHK Technology } & Project status & pilot & commercial & prototype & & & \\
\hline & Geometry and orientation & & & & & & \\
\hline MHK Technology & Number of devices & $0-3$ & $3--10$ & $10--50$ & $>50$ & & \\
\hline MHK Technology & Geometry & cross channel & along channel & other configuration & & & \\
\hline MHK Technology & Vertical location in water column & Surface & Bottom & Water column & Mid & & \\
\hline \multirow{2}{*}{ MHK Technology } & Orientation wrt wave direction & Parallel & Perpendicular & Point & Overtopping & N/A & \\
\hline & $\begin{array}{l}\text { Rotor Configuration } \\
\end{array}$ & & & & & & \\
\hline MHK Technology & Size of turbine swept area $\left(\mathrm{m}^{2}\right)$ & $20-60$ & $60-100$ & $100-200$ & $200-500$ & N/A & \\
\hline MHK Technology & Orientation of axis wrt flow & Axial & Transverse & N/A & & & \\
\hline MHK Technology & Orientation of blades wrt axis & Perpendicular & Parallel & N/A & & & \\
\hline MHK Technology & Shape of leading edge of turbine blade & Rounded & Sharp & N/A & & & \\
\hline MHK Technology & Pitched blades & Yes, fixed & Yes, adjustable & No & N/A & & \\
\hline MHK Technology & Rotor diameter (m) & $3--5$ & $5--7$ & 7--10 & $10--15$ & N/A & \\
\hline MHK Technology & Dynamic rotor seal & Yes & No & N/A & & & \\
\hline \multirow[t]{2}{*}{ MHK Technology } & Gearbox & Yes & No & & & & \\
\hline & Device Configuration & & & & & & \\
\hline MHK Technology & Yaw mechanism & Yes & No & & & & \\
\hline MHK Technology & Ducted/venturi & No duct & Shallow duct & Shallow venturi & Deep venturi & & \\
\hline MHK Technology & Bearings & Yes & No & & & & \\
\hline MHK Technology & External generator & Yes & No & & & & \\
\hline MHK Technology & Turbine/generator located onsite in water & Yes & No & & & & \\
\hline MHK Technology & Surface-Piercing & Yes & No & & & & \\
\hline MHK Technology & Power cable location & Buried & Surface-laid & & & & \\
\hline MHK Technology & Power cable landfall & Directional drilling & Through nearshore & & & & \\
\hline MHK Technology & Coupled with bidirectional airflow turbine & Yes & No & & & & \\
\hline MHK Technology & Impedance matching of waves & Yes & No & & & & \\
\hline \multirow{2}{*}{ MHK Technology } & Adjustable natural resonance frequency & Yes & No & N/A & & & \\
\hline & Fouling, Corrosion Protection & & & & & & \\
\hline MHK Technology & Anti-fouling coating/paint & Yes & No & & & & \\
\hline MHK Technology & Surface area covered by anti-fouling coating/paint $(\mathrm{m}$ & $0-30$ & $30-60$ & $>60$ & None & & \\
\hline \multirow[t]{2}{*}{ MHK Technology } & Composition of anti-fouling coating/paint & Toxic & Non-toxic & None & & & \\
\hline & Mooring/Foundation & & & & & & \\
\hline MHK Technology & Footprint on bottom $\left(\mathrm{m}^{2} /\right.$ device $)$ & $5-8$ & 8-11 & 11-14 & $>14$ & & \\
\hline MHK Technology & Distance from edge of waterway & $0-20 \mathrm{~m}$ & $20-60 \mathrm{~m}$ & $60-150 \mathrm{~m}$ & $>150 \mathrm{~m}$ & & \\
\hline MHK Technology & Mooring method & Gravity-mounted & Driven piles & Anchored & & & \\
\hline \multirow[t]{2}{*}{ MHK Technology } & Anchoring cables & Slack & Taut & N/A & & & \\
\hline & \begin{tabular}{|c|} 
Resource Characterization \\
\end{tabular} & & & & & & \\
\hline MHK Technology & Power density $\left(\mathrm{kW} / \mathrm{m}^{2}\right)$ & $0-3$ & $3--10$ & $10--15$ & $>15$ & & \\
\hline MHK Technology & Power rating of device $(\mathrm{kW})$ & $10-50$ & $50-100$ & $100-1000$ & $>1000$ & & \\
\hline MHK Technology & Approximate power output at $2.5 \mathrm{~m} / \mathrm{s}(\mathrm{kW})$ & $10-50$ & $50-100$ & $100-200$ & $>200$ & & \\
\hline \multirow[t]{2}{*}{ MHK Technology } & Resonance wave period & Long & Short & N/A & & & \\
\hline & Bottom & & & & & & \\
\hline Site Characteristics & Sediment grain size & Bedrock & Boulder $(>256 \mathrm{~mm})$ & Cobble $(>64 \mathrm{~mm})$ & Gravel (>4mm) & Sand $(>.06 \mathrm{~mm})$ & Mud/clay $(<.06 \mathrm{~mm})$ \\
\hline Site Characteristics & Bottom roughness & Smooth & Rough & & & & \\
\hline Site Characteristics & Vegetation present & Rooted vegetation & Floating & None & & & \\
\hline Site Characteristics & Vegetation type & SAV & Macroalgae & None & & & \\
\hline \multirow[t]{2}{*}{ Site Characteristics } & Bottom slope (\%) & $0-1$ & $1-2$ & $2-4$ & $>4$ & & \\
\hline & \begin{tabular}{|l} 
Flow and Wave \\
\end{tabular} & & & & & & \\
\hline Site Characteristics & Water depth $(\mathrm{m})$ & $<10$ & $10-40$ & $40-100$ & $>100$ & N/A & \\
\hline Site Characteristics & Avg flow/current speed $(\mathrm{m} / \mathrm{s})$ & $0-2$ & $2-4$ & $4-6$ & $6--8$ & $>8$ & N/A \\
\hline Site Characteristics & Peak flow/current speed $(\mathrm{m} / \mathrm{s})$ & $0-2$ & $2--4$ & $4--6$ & N/A & & \\
\hline Site Characteristics & Tidal amplitude $(\mathrm{m})$ & $0-2$ & $2--4$ & $4--6$ & $>6$ & None & \\
\hline Site Characteristics & Flow directionality & one way & two way & N/A & & & \\
\hline Site Characteristics & Avg Wave Height (m) & $0-.5 \mathrm{~m}$ & $.5-1 \mathrm{~m}$ & $1-1.5 \mathrm{~m}$ & $1.5-2 \mathrm{~m}$ & $\mathrm{~N} / \mathrm{A}$ & \\
\hline Site Characteristics & Peak Wave Height $(\mathrm{m})$ & $0-2 m$ & $2-3 m$ & $3-4 m$ & $4-5 \mathrm{~m}$ & N/A & \\
\hline Site Characteristics & Avg Wave Period (sec) & $1-5 s$ & 5-10s & $10-15 \mathrm{~s}$ & $>15 \mathrm{~s}$ & $\mathrm{~N} / \mathrm{A}$ & \\
\hline Site Characteristics & Peak Wave Period (sec) & 5-10s & $10-15 \mathrm{~s}$ & $15-20 \mathrm{~s}$ & $20-25 \mathrm{~s}$ & $>25 \mathrm{~s}$ & $\mathrm{~N} / \mathrm{A}$ \\
\hline Site Characteristics & Avg Wave Length $(\mathrm{m})$ & $0-4 m$ & $4-6 m$ & $6-8 \mathrm{~m}$ & $8-10 m$ & $>10 \mathrm{~m}$ & N/A \\
\hline Site Characteristics & Peak Wave Length $(\mathrm{m})$ & $<6 \mathrm{~m}$ & 6-10m & $10-15 \mathrm{~m}$ & $>15 \mathrm{~m}$ & N/A & \\
\hline Site Characteristics & Avg streamflow (cubic ft/sec) & $<5,000$ & $5,000-10,000$ & $10,000-50,000$ & $50,000-100,000$ & $>100,000$ & $\mathrm{~N} / \mathrm{A}$ \\
\hline Site Characteristics & Peak streamflow (cubic ft/sec) & $10,000-20,000$ & $20,000-50,000$ & $50,000-200,000$ & $200,000-300,000$ & $>300,000$ & N/A \\
\hline
\end{tabular}




\section{Dimensions, Attributes, and States (contd)}

\begin{tabular}{|c|c|c|c|c|c|c|c|}
\hline & Water Quality Parameters & & & & & & \\
\hline Waterbody & Phosphorus concentration $>0.1 \mathrm{mg} / \mathrm{L}$ & Yes & No & & & & \\
\hline Waterbody & Nitrogen concentration $>1 \mathrm{mg} / \mathrm{L}$ & Yes & No & & & & \\
\hline Waterbody & Chlorophyll a concentration $>10$ ug-at/L & Yes & No & & & & \\
\hline Waterbody & Salinity (ppt) & $<0.5$ & $0.5-10$ & $10--30$ & $>30$ & & \\
\hline Waterbody & $\mathrm{pH}$ & $<6$ & $6.5-7.5$ & $>7.5$ & & & \\
\hline Waterbody & Oxygen concentration $(\mathrm{mg} / \mathrm{L})$ & $0-2$ & $2--5$ & $>5$ & & & \\
\hline Waterbody & Annual average temperature $(\operatorname{deg} C)$ & $0-5$ & $5--10$ & $10--15$ & $15-20$ & & \\
\hline Waterbody & Turbidity (NTU) & $0-1$ & $1--10$ & $>10$ & & & \\
\hline \multirow[t]{2}{*}{ Waterbody } & Silicate >20ug-at/l & Yes & No & & & & \\
\hline & Physical Characteristics & & & & & & \\
\hline Waterbody & Geographic zone & Tropical & Temperate & Subarctic & & & \\
\hline Waterbody & Estuarine & Fjord & Well mixed & Partially mixed & Salt wedge & N/A & \\
\hline Waterbody & Ocean & Coastal & Open ocean & N/A & & & \\
\hline Waterbody & Nearshore & Intertidal & Subtidal & Dry land & N/A & & \\
\hline Waterbody & Riverine & Streams & Tributaries & Large Rivers & N/A & & \\
\hline Waterbody & Tidal prism $\left(\times 10^{6} \mathrm{~m}^{2}\right)$ & $<0.5$ & $0.5-3$ & $>3$ & $\mathrm{~N} / \mathrm{A}$ & & \\
\hline Waterbody & Tidal regime & diurnal & semidirunal & $\mathrm{N} / \mathrm{A}$ & & & \\
\hline Waterbody & Range of river stage & $<0.5 \mathrm{~m}$ & $0.5-3 m$ & $>3 \mathrm{~m}$ & $\mathrm{~N} / \mathrm{A}$ & & \\
\hline Waterbody & Avg flow/current speed (m/s) & $0-2$ & $2-4$ & $4-6$ & $6--8$ & $>8$ & N/A \\
\hline Waterbody & Avg streamflow (cubic ft/sec) & $<5,000$ & $5,000-10,000$ & $10,000-50,000$ & $50,000-100,000$ & $>100,000$ & N/A \\
\hline Waterbody & Seasonal flow variability & Yes & No & N/A & & & \\
\hline Waterbody & Avg wave height & $0-.5 \mathrm{~m}$ & $.5-1 \mathrm{~m}$ & $1-1.5 m$ & $1.5-2 \mathrm{~m}$ & N/A & \\
\hline Waterbody & Avg Wave Period (sec) & $1-5 s$ & 5-10s & $10-15 s$ & $>15 s$ & N/A & \\
\hline Waterbody & Avg wave length & $0-4 m$ & $4-6 m$ & $6-8 m$ & $8-10 m$ & $>10 \mathrm{~m}$ & N/A \\
\hline Waterbody & Prevailing wave direction & NW-NE & NE-SE & SE-SW & SW-NW & & \\
\hline Waterbody & Prevailing wind speed (knots) & $0-10$ & $10--30$ & $>30$ & & & \\
\hline Waterbody & Prevailing wind direction & NW-NE & NE-SE & SE-SW & SW-NW & & \\
\hline Waterbody & Seasonality of prevailing wind/wave direction & Yes & Yes & & & & \\
\hline Waterbody & Frequency of major storm events & $0-2$ peryear & 3-5 per year & $>5$ per year & & & \\
\hline Receptors & Water quality & $0-2 \mathrm{mg} /$ L Oxygen & 2--5 mg/L Oxygen & $>5 \mathrm{mg} /$ L Oxygen & & & \\
\hline \multirow[t]{2}{*}{ Receptors } & Sedimentation pattern & Scoured & Accretional & Erosional & & & \\
\hline & Reptiles & & & & & & \\
\hline Receptors & Chelonians (sea turtles, terrapin) & Present & Absent & & & & \\
\hline Receptors & Chelonians seasonality of presence & Year round & Spring & Summer & Fall & Winter & N/A \\
\hline Receptors & Chelonians endangered/special status & Yes & No & N/A & & & \\
\hline Receptors & Chelonians behavior at site & Transiting & Foraging & Mating & Nesting & N/A & \\
\hline Receptors & Chelonians commercially/recreationally/culturall & Yes & No & N/A & & & \\
\hline Receptors & Other reptiles & Present & Absent & & & & \\
\hline Receptors & Other reptiles seasonality of presence & Year round & Spring & Summer & Fall & Winter & N/A \\
\hline Receptors & Other reptiles endangered/special status & Yes & No & N/A & & & \\
\hline Receptors & Other reptiles behavior at site & Transiting & Foraging & Mating & Nesting & N/A & \\
\hline \multirow[t]{2}{*}{ Receptors } & Other reptiles commercially/recreationally/cultu & Yes & No & N/A & & & \\
\hline & Aquatic and Marine Mammals & & & & & & \\
\hline Receptors & Cetaceans (whales, porpoise) & Present & Absent & & & & \\
\hline Receptors & Cetaceans seasonality of presence & Year round & Spring & Summer & Fall & Winter & N/A \\
\hline Receptors & Cetaceans endangered/special status & Yes & No & N/A & & & \\
\hline Receptors & Cetaceans behavior at site & Transiting & Foraging & Mating & Rearing & N/A & \\
\hline Receptors & Pinnipeds (seals, sea lions) & Present & Absent & & & & \\
\hline Receptors & Pinnipeds seasonality of presence & Year round & Spring & Summer & Fall & Winter & N/A \\
\hline Receptors & Pinnipeds endangered/special status & Yes & No & N/A & & & \\
\hline Receptors & Pinnipeds behavior at site & Transiting & Foraging & Mating & Rearing & N/A & \\
\hline Receptors & Lutrinae (sea otter, river otter) & Present & Absent & & & & \\
\hline Receptors & Lutrinae seasonality of presence & Year round & Spring & Summer & Fall & Winter & N/A \\
\hline Receptors & Lutrinae endangered/special status & Yes & No & $\mathrm{N} / \mathrm{A}$ & & & \\
\hline Receptors & Lutrinae behavior at site & Transiting & Foraging & Mating & Rearing & N/A & \\
\hline Receptors & Other aquatic/marine mammals & Present & Absent & & & & \\
\hline Receptors & Other aquatic/marine mammals seasonality of pr & Year round & Spring & Summer & Fall & Winter & $\mathrm{N} / \mathrm{A}$ \\
\hline Receptors & Other aquatic/marine mammals endangered/spe & Yes & No & N/A & & & \\
\hline Receptors & Other aquatic/marine mammals behavior at site & Transiting & Foraging & Mating & Rearing & N/A & \\
\hline
\end{tabular}




\section{Dimensions, Attributes, and States (contd)}

\begin{tabular}{|c|c|c|c|c|c|c|c|}
\hline & Fish & & & & & & \\
\hline Receptors & Elasmobranchs + Acipenseridae (sharks + sturgeon) & Present & Absent & & & & \\
\hline Receptors & Elasmobranchs + Acipenseridae seasonality of presen & Year round & Spring & Summer & Fall & Winter & N/A \\
\hline Receptors & Elasmobranchs + Acipenseridae engendered/special s & Yes & No & N/A & & & \\
\hline Receptors & Elasmobranchs + Acipenseridae behavior at site & Transiting & Foraging & Schooling & Resident & Mating & N/A \\
\hline Receptors & Elasmobranchs + Acipenseridae commercially/recreat & tYes & No & N/A & & & \\
\hline Receptors & Salmonids (salmon + trout) & Present & Absent & & & & \\
\hline Receptors & Salmonids seasonality of presence & Year round & Spring & Summer & Fall & Winter & N/A \\
\hline Receptors & Salmonids endangered/special status & Yes & No & N/A & & & \\
\hline Receptors & Salmonids behavior at site & Transiting & Foraging & Schooling & Mating & N/A & \\
\hline Receptors & Salmonids migration & Out migrating juvenil/ & Out migrating sub-ad & in migrating adult & N/A & & \\
\hline Receptors & Salmonids migrating depth & Near surface & mid-water column & near bottom & N/A & & \\
\hline Receptors & Salmonids commercially/recreationally/culturally imp & Yes & No & N/A & & & \\
\hline Receptors & Bottomfish (sole, flounder, halibut, shad) & Present & Absent & & & & \\
\hline Receptors & Bottomfish seasonality of presence & Year round & Spring & Summer & Fall & Winter & N/A \\
\hline Receptors & Bottomfish endangered/special status & Yes & No & N/A & & & \\
\hline Receptors & Bottomfish behavior at site & Transiting & Foraging & Schooling & Resident & Mating & N/A \\
\hline Receptors & Bottomfish commercially/recreationally/culturally im & Yes & No & N/A & & & \\
\hline Receptors & Reefish (rockfish, etc) & Present & Absent & & & & \\
\hline Receptors & Reefish seasonality of presence & Year round & Spring & Summer & Fall & Winter & N/A \\
\hline Receptors & Reefish endangered/special status & Yes & No & N/A & & & \\
\hline Receptors & Reefish behavior at site & Transiting & Foraging & Schooling & Resident & Mating & N/A \\
\hline Receptors & Reefish commercially/recreationally/culturally import & tYes & No & N/A & & & \\
\hline Receptors & Other fish & Present & Absent & & & & \\
\hline Receptors & Other fish seasonality of presence & Year round & Spring & Summer & Fall & Winter & N/A \\
\hline Receptors & Other fish endangered/special status & Yes & No & N/A & & & \\
\hline Receptors & Other fish behavior at site & Transiting & Foraging & Schooling & Resident & Mating & N/A \\
\hline \multirow[t]{2}{*}{ Receptors } & Other fish commercially/recreationally/culturally imp & Yes & No & N/A & & & \\
\hline & Aquatic and Marine Invertebrates & & & & & & \\
\hline Receptors & Crustaceans (crabs, lobsters, shrimp, barnacles) & Present & Absent & & & & \\
\hline Receptors & Crustaceans seasonality of presence & Year round & Spring & Summer & Fall & Winter & N/A \\
\hline Receptors & Crustaceans endangered/special status & Yes & No & N/A & & & \\
\hline Receptors & Crustaceans behavior at site & Transiting & Foraging & Resident & Mating & $\mathrm{N} / \mathrm{A}$ & \\
\hline Receptors & Crustaceans commercially/recreationally/culturally in & Yes & No & & & & \\
\hline Receptors & Benthic infauna (mollusks, worms) & Present & Absent & & & & \\
\hline Receptors & Benthic infauna seasonality of presence & Year round & Spring & Summer & Fall & Winter & N/A \\
\hline Receptors & Benthic infauna endangered/special status & Yes & No & N/A & & & \\
\hline Receptors & Benthic infauna behavior at site & Transiting & Foraging & Resident & Mating & $\mathrm{N} / \mathrm{A}$ & \\
\hline Receptors & Benthic infauna commercially/recreationally/culturall| & NYes & No & $\mathrm{N} / \mathrm{A}$ & & & \\
\hline Receptors & Other invertebrates & Sessile & Motile & None & & & \\
\hline Receptors & Other invertebrates seasonality of presence & Year round & Spring & Summer & Fall & Winter & N/A \\
\hline Receptors & Other invertebrates endangered/special status & Yes & No & $\mathrm{N} / \mathrm{A}$ & & & \\
\hline Receptors & Other invertebrates behavior at site & Transiting & Foraging & Resident & Mating & N/A & \\
\hline \multirow[t]{2}{*}{ Receptors } & Other invertebrates commercially/recreationally/cult & Yes & No & $\mathrm{N} / \mathrm{A}$ & & & \\
\hline & \begin{tabular}{|c|} 
Diving birds \\
\end{tabular} & & & & & & \\
\hline Receptors & Diving birds & Present & Absent & & & & \\
\hline Receptors & Diving birds seasonality of presence & Year round & Spring & Summer & Fall & Winter & N/A \\
\hline Receptors & Diving birds endangered/special status & Yes & No & N/A & & & \\
\hline Receptors & Diving birds behavior at site & Transiting & Foraging & Resident & Mating & Rearing & N/A \\
\hline Receptors & Other aquatic/marine-dependant birds & Present & Absent & & & & \\
\hline Receptors & Other aquatic/marine-dependant birds seasonality of & Year round & Spring & Summer & Fall & Winter & N/A \\
\hline Receptors & Other aquatic/marine-dependant birds endangered/sh & Yyes & No & N/A & & & \\
\hline \multirow[t]{2}{*}{ Receptors } & Other aquatic/marine-dependant birds behavior at sit & Transiting & Foraging & Resident & Mating & Rearing & N/A \\
\hline & \begin{tabular}{|c|} 
Aquatic and Marine Plants + Alga \\
\end{tabular} & & & & & & \\
\hline Receptors & Macroalgae (e.g. Laminaria, Nereocystis, etc) & Present & Absent & & & & \\
\hline Receptors & Macroalgae seasonality of presence & Year round & Spring & Summer & Fall & Winter & N/A \\
\hline Receptors & Macroalgae endangered/special status & Yes & No & N/A & & & \\
\hline Receptors & Seagrass (e.g. Zostera, Phyllospadix, etc) & Present & Absent & & & & \\
\hline Receptors & Seagrass seasonality of presence & Year round & Spring & Summer & Fall & Winter & N/A \\
\hline \multirow[t]{2}{*}{ Receptors } & Seagrass endangered/special status & Yes & No & N/A & & & \\
\hline & \begin{tabular}{|c|} 
Special Habitats \\
\end{tabular} & & & & & & \\
\hline Receptors & Coral reef & Present & Absent & & & & \\
\hline Receptors & Coral reef protected/special status & Yes & No & N/A & & & \\
\hline Receptors & Rocky reef & Present & Absent & & & & \\
\hline Receptors & Rocky reef protected/special status & Yes & No & & & & \\
\hline Receptors & Kelp forest & Present & Absent & & & & \\
\hline Receptors & Kelp forest protected/special status & Yes & No & N/A & & & \\
\hline Receptors & Deep water corals/sponges & Present & Absent & & & & \\
\hline Receptors & Deep water corals/sponges protected/special status & Yes & No & N/A & & & \\
\hline
\end{tabular}




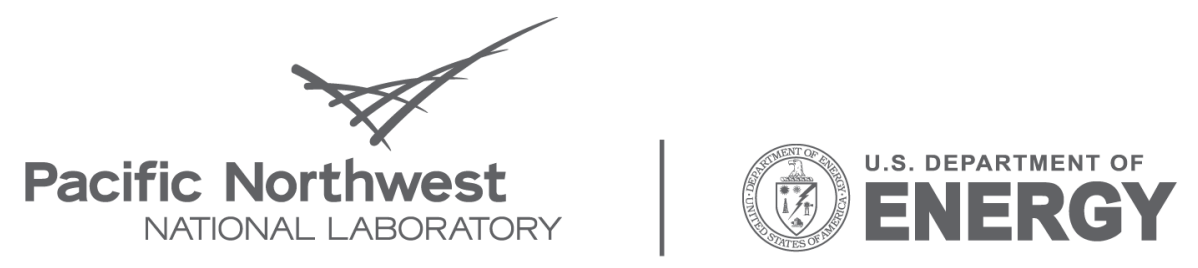

Proudly Operated by Battelle Since 1965

902 Battelle Boulevard

P.O. Box 999

Richland, WA 99352

1-888-375-PNNL (7665)

www.pnl.gov 